\section{Pengaruh Likuiditas, Profitabilitas, dan Pertumbuhan Perusahaan Terhadap Penerimaan Opini Audit Going Concern Perusahaan Farmasi}

\author{
Muhamad Zaelani dan Amrulloh \\ Rogram Studi S1 Akuntansi, Fakultas Bisnis \\ Institut Bisnis Dan Informatika Kesatuan Bogor
}

E-Mail : m.zaelani@ibik.ac.id
Financial Ratio and Going Concern Audit

Opinion

\begin{abstract}
The survival of a company is always attached to its influence with the importance of the role of a company's business management in managing the company so that it can continue to run and develop, in addition to the role of company sustainability management, it also extends to the role of auditors related to the company, because auditors are responsible for always evaluating performance and sustainability status. corporate life (Alichia, 2008).. This study is a study to examine the effect of liquidity, profitability, and company growth on the acceptance of going concern audit opinions. This research is a quantitative research with correlation analysis method, where the researcher shows several relationships of certain variables. The results of the data selection using the purposive sampling method, which is a sampling technique using certain criteria such as Pharmaceutical companies listed on the Indonesia Stock Exchange (IDX) in 2017 to 2019 with a sample of 8 companies and a sample of 24 financial statements used. financial statements. The data analysis technique used is logistic regression analysis technique, using the SPSS 26 program. The results of the regression analysis show that the three hypotheses tested state that the variables of Liquidity, Profitability, and Company Growth support the hypothesis. So, these three variables do not affect the auditor in giving a going concern audit opinion.
\end{abstract}

Keywords: Going Concern Audit Opinion, Liquidity, Profitability, and Company Growth

\begin{abstract}
ABSTRAK
Kelangsungan hidup suatu perusahaan selalu melekat pengaruhnya dengan pentingnya peran manajemen bisnis suatu perusahaan dalam mengelola perusahaan tersebut agar terus bisa berjalan dan berkembang, selain peran manajemen keberlangsungan perusahaan juga melebar pada peran auditor terkait perusahaa tersebut, karena auditor bertanggung jawab untuk selalu mengevaluasi kinerja serta status keberlangsungan hidup perusahaan (Alichia, 2008). Penelitian ini merupakan penelitian untuk menguji pengaruh Likuiditas, Profitabilitas, dan Pertumbuhan perusahaan terhadap penerimaan opini audit going concern. Penelitian ini merupakan penelitia kuantitatif dengan metode analisis korelasi, dimana peneliti menunjukkan beberapa hubungan variabel tertentu. Hasil dari seleksi data dengan menggunakan metode purposive sampling, yaitu teknik pengambilan sampel dengan menggunakan kriteria tertentu seperti perusahaan Farmasi yang tercatat di Bursa Efek Indonesia (BEI) pada tahun 2017 sampai dengan 2019 dengan sampel perusahaan sebanyak 8 perusahaan dan sample laporan keuangan yang digunakan sebanyak 24 laporan keuangan. Teknik analisis data yang digunakan yaitu teknik analisis regresi logistik, dengan menggunakan program SPSS 26. Hasil dari analisis regresi menunjukkan bahwa dari tiga hipotesis yang diuji menyatakan bahwa variabel Likuiditas, Profitabilitas, dan Pertumbuhan Perusahaan mendukung hipotesis. Ketiga Variabel tidak mempengaruhi auditor dalam pemberian opini audit going concern.
\end{abstract}

Kata kunci: opini audit going concern, likuiditas, profitabilitas, pertumbuhan perusahaan

Submitted: APRIL 2021

Accepted: JULI 2021

\section{9}

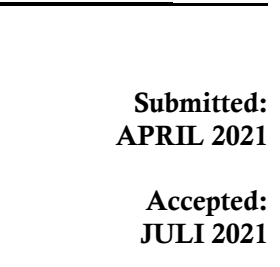


Financial Ratios and Going Concern Audit Opinion

\section{PENDAHULUAN}

Catatan industri farmasi yang dilakukan kementrian perindustrian mengungkapkan bahwa Produk obat tradisional dan obat kimia tumbuh sejumlah 4,46 persen tahun lalu, dan industri pengolahan nonmigas pun mencapai 2,78 persen antara kontribusi industri terhadap Produk Domestik Bruto (PDB) pada Tahun 2018 (Anggraini: Katadata.co.id, 02 November 2020). Maka dalam hal ini juga berpeluang pada kelangsungan hidup perusahaan pada sektor farmasi dimana mempengaruhi pertumbuhan perusahaan dan minat investor untuk menanamkan modalnya.

Maka dari itu perusahaan wajib membuat laporan keuangan yang berkualitas karena laporan keuangan tersebut akan dijadikan acuan pengambilan keputusan oleh pihak yang berkepentingan misalnya investor, pemerintah, perbankan, maupun perusahaan itu sendiri, Untuk itu diperlukan adanya peran auditor independen dalam memeriksa laporan keuangan perusahaan. Jadi Laporan perusahaan misalnya laporan keuangan akan lebih mudah mendapatkan keyakinan atau kepercayaan pihak yang berkepentingan terhadap laporan keuangan tersebut, jika laporan keuangan perusahaan menunjukan kinerja dan kondisi perusahaan yang sebernarnya maka auditor akan memberikan opini wajar (Djoko dan Yanti, 2019). Kasus pada sektor perusahaan pertambangan yaitu PT Sigmagold Inti Perkasa tercatat di Bursa Efek Indonesia yang terkena delisting secara paksa (forced delisting). PT Sigmagold Inti Perkasa (TMPI) telah menjadi contoh bahwa perseroan gagal memberikan rencana ke depan untuk kelangsungan usaha (going concern). Adapun yang menjadi catatan dari proses yang cukup panjang dan berujung pada penghapusan pencatatan saham ini adalah tanggung jawab dari dewan direksi dan dewan komisaris perseroan.

Bursa Efek Indonesia (BEI) resmi menghapus pencatatan efek TMPI dari papan perdagangan efek pada 11 November 2019. BEI menghapus efek emiten berkode saham TMPI dengan merujuk pada Peraturan Bursa Nomor I-I tentang penghapusan pencatat atau delisting dan pencatatan kembali (relisting). Bursa menghapus saham perusahaan tercatat dengan dua kondisi (Tari: Bisnis.com, 16 Desember 2020). Pertama, perseroan mengalami kondisi atau peristiwa yang secara signifikan berpengaruh negative terhadap kelangsungan usaha perusahaan tercatat, baik itu secara finansial atau secara hukum atau terhadap kelangsungan status perusahaan tercatat yang tidak dapat menunjukkan indikasi pemulihan yang memadai. Kedua, saham perusahaan tercatat akibat suspensi di Pasar Reguler dan Pasar Tunai hanya diperdagangkan di pasar negosiasi sekurang-kurangnya selama 24 bulan terakhir.

Dalam pengumuman BEI, Kepala Divisi Penilaian Perusahaan 2 Vera Florida dan Kepala Divisi Pengaturan dan Operasional Perdagangan Irvan Susandy menegaskan kendati sudah tidak tercatat di BEI, Sigmagold Inti Perkasa masih merupakan perusahaan publik.

Dengan demikian, perseroan tetap wajib memperhatikan kepentingan pemegang saham publik dan mematuhi ketentuan mengenai keterbukaan informasi dan pelaporan kepada Otoritas Jasa Keuangan (Tari: Bisnis.com, 16 Desember 2020).

Opini audit going concern adalah opini yang dikeluarkan oleh auditor karena terdapat kesanksian besar mengenai kemampuan perusahaan dalam mempertahankan kelangsungan hidupnya (Standar Profesional Akuntan Publik, 2011). Serta Kelangsungan hidup suatu perusahaan selalu melekat pengaruhnya dengan pentingnya peran manajemen bisnis suatu perusahaan dalam mengelola perusahaan tersebut agar terus bisa berjalan dan berkembang, selain peran manajemen keberlangsungan perusahaan juga melebar pada peran auditor terkait perusahaa tersebut, karena auditor bertanggung jawab untuk selalu mengevaluasi kinerja serta status keberlangsungan hidup perusahaan (Alichia, 2008). Menurut Listantri dan Mudjiyanti (2016) menjelaskan bahwa keberlangsungan hidup perusahaan atau bisa disebut dengan Going Concern merupakan suatu opini yang dilontarkan seorang audit dimana suatu entitas dianggap dapat terus berjalan usahanya dalam jangka waktu yang cukup lama, atau memastikan jika perusahaan tersebut tidak akan kolaps atau bangkrut dalam waktu dekat, indikasi dari kebangkrutan merupakan dugaan atas keraguan seorang auditor terhadap kelangsungan 
hidup suatu perusahaan. Atas Keraguan terhadap kelangsungan hidup suatu perusahaan maka Pemberian opini audit going concern merupakan keputusan yang cukup sulit bagi auditor. "Karena auditor itu sendiri bertanggung jawab atas perolehan bukti yang tepat dan cukup atas pengunaan asumsi suatu kelangsungan hidup usaha oleh manajemenperusahaan dalam penyajian laporan keuangannya sekaligus menyimpulkan apakah ada suatu ketidakpastian yang material atas kemampuan perusahaan dalam menjaga kelangsungan hidup usahanya" (Gultom, 2019). Faktor yang dapat mempengaruhi opini audit going concern salah satunya pertumbuhan perusahaan, dimana pertumbuhan perusahaan ini yang menggambarkan bagaimana kinerja suatu perusahaan dalam kegiatan ekonomi dalam industrinya (Sutedja, 2010). Dan pada pertumbuhan perusahaan berpengaruh negatif terhadap opini going concern dalam penelitian yang dikemukakan oleh (Kristiana, 2012).

ROA merupakan suatu perhitungan yang dapat menunjukan kemampuan perusahaan dalam menghasilkan laba dengan menghitung Total asset atau total aktiva yang dimiliki perusahaan pada periode tertentu (Arma, 2013). Pada penelitian yang telah dilakukan oleh Yani, Asmeri, Andini (2018) menunjukan bahwa profitabilitas berpengaruh signifikan terhadap opini audit going concern.

Lalu faktor lainnya yaitu Likuiditas yang merupakan rasio yang menunjukan kemampuan perusahaan dalam memenuhi setiap utang atau kewajiban jangka pendek perusahaan (Kasmir, 2016). Pada penelitian yang dilakukan menurut Sussanto, Aquariza (2013) menjelaskan bahwa likuiditas tidak memberikan pengaruh terhadap opini audit going concern.

Penelitian-penelitian yang dilakukan mengenai opini going concern di Indonesia antara lain dilakukan oleh kristiana (2012) yang berjudul "Pengaruh Ukuran Perusahaan, Profitabilitas, likuiditas, Pertumbuhan Perusahaan Terhadap Opini Audit Going Concern Pada Perusahaan Manufaktur yang Terdaftar di Bursa Efek Indonesia (BEI)" untuk profitabilitas, likuiditas, dan pertumbuhan perusahaan memberikan pengaruh negatif terhadap opini audit going concern, sedangkan ukuran perusahaan tidak berpengaruh signifikan terhadap opini audit going concern. Dalam penelitian yang dikemukakan oleh Yani, Asmeri, Andini (2018) yang berjudul "Analisis Pengaruh Profitabilitas, Cash Flow, Dan Kebijakan Manajemen Terhadap Opini Audit Going Concern Pada Perusahaan Manufaktur Yang Terdaftar Di Bursa Efek Indonesia" menunjukkan bahwa untuk profitabilitas berpengaruh signifikan terhadap opini audit going concern pada perusahaan manufaktur, untuk variabel cash flow tidak berpengaruh signifikan terhadap opini audit going concern, dan kebijakan manajemen tidak mempengaruhi secara signifikan terhadap opini audit going concern. Penelitian yang dilakukan oleh Sussanto, Aquariza (2013) yang berjudul "Analisis Pengaruh Opini Audit Tahun Sebelumnya, Kualitas Auditor, Profitabilitas, Likuiditas, Dan Solvabilitas Terhadap Pemberian Opini Auditor Going Concern Pada Perusahaan Consumer Goods Industry Yang terdaftar di Bursa Efek Indonesia" menjelaskan bahwa opini audit tahun sebelumnya berpengaruh positif terhadap opini audit going concern, Kualitas audit mempengaruhi secara positif terhadap penerimaan opini going concern, profitabilitas tidak memiliki pengaruh terhadap penerimaan opini going concern, likuiditas tidak berpengaruh, dan solvabilitas memiliki pengaruh signifikan terhadap pemberian opini Going Concern.

Perbedaan dari penelitian diatas yaitu ada pada subjek penelitiannya, sektor perusahaan yang diteliti, tahun penelitian yang dilakukan, dan variable independennya. Tujuan Penelitian ini adalah sebagai berikut :

1. Untuk mengetahui Seberapa besar pengaruh Likuiditas Perusahaan sektor farmasi yang terdaftar di BEI tahun 2017 - 2019 terhadap opini audit Going Concern.

2. Untuk mengetahui Seberapa besar pengaruh Profitabilitas Perusahaan sektor farmasi yang terdaftar di BEI tahun 2017 - 2019 terhadap opini audit Going Concern.

3. Untuk mengetahui Seberapa besar pengaruh Pertumbuhan Perusahaan sektor farmasi yang terdaftar di BEI tahun 2017 - 2019 terhadap opini audit Going Concern.
Financial Ratios and Going Concern Audit Opinion 
Financial Ratios and Going Concern Audit Opinion

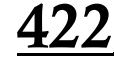

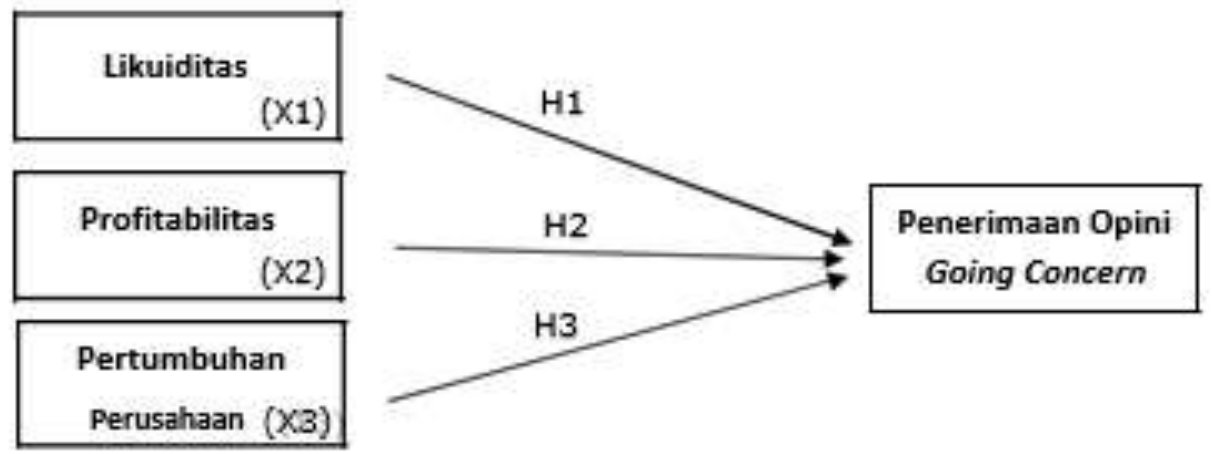

Hipotesis Penelitian

Gambar 1 Kerangka Pemikiran Teoritis/Konseptual

Berdasarkan Hasil penelitian terdahulu dan Kerangka pemikiran yang telah Peneliti Buat makan peneliti dapat menyimpulkan Hipotesis Sebagai Berikut:

H1 : Likuiditas Tidak berpengaruh terhadap penerimaan Opini Audit Going Concern Pada Perusahaan Farmasi yang terdaftar di Bursa Efek Indonesia 2017-2019

H2 : Profitabilitas Tidak berpengaruh terhadap terhadap penerimaan Opini Audit Going Concern Pada Perusahaan Farmasi yang terdaftar di BEI tahun 2017-2019

H3 : Pertumbuhan Perusahaan Tidak berpengaruh terhadap penerimaan opini audit Going Concern Pada Perusahaan Farmasi yang terdaftar di BEI tahun 2017-2019

\section{METODE PENELITIAN}

Jenis penelitian yang digunakan adalah penelitian kuantitatif yang berupa bilangan atau angka. Dengan pendekatan deskriptif, dilakukan untuk menjelaskan variabel yang diteliti pada suatu situasi, sedangkan data yang diambil merupakan data sekunder mengacu pada informasi yang dikumpulkan dari sumber yang telah ada (Utami, 2020).

Subjek penelitian merupakan nilai dari orang, sifat atau atribut, dan objek penelitian merupakan variabel yang ditentukan untuk dipelajari guna menarik kesimpulan (Sugiyono, 2013). Objek pada penelitian ini adalah Likuiditas (X1), Profitabilitas (X2), Pertumbuhan perusahaan (X3) dan Audit Going Concern (Y). Sedangkan subjek pada penelitian ini adalah perusahaan sector farmasi yang terdaftar di Bursa Efek Indonesia pada tahun 2017-2019.

Variabel dibagi menjadi dua yaitu variabel dependen dan independen dalam penelitian ini variable dependennya yaitu (Opini audit going concern) dan variabel independennya yaitu (Likuiditas, Profitabilitas, Dan Pertumbuhan Perusahaan). Definisi variablenya sebagai berikut:

\begin{tabular}{|c|c|c|c|}
\hline Variabel & Definisi & Indikator & Skala \\
\hline $\begin{array}{l}\text { Variabel } \\
\text { Dependen } \\
(Y) \\
\text { Opini } \quad \text { Audit } \\
\text { Going Concern }\end{array}$ & $\begin{array}{l}\text { Opini audit Going Concern yaitu suatu pernyataan yang } \\
\text { diungkapkan oleh seorang auditor untukt ujuan } \\
\text { mengevaluasi apakah ditemukan adanya kesanksian } \\
\text { tentang bagaimana kemampuan suatu perusahaanatau } \\
\text { organisasi dalam mempertahankan kelangsungan } \\
\text { hidupnya SA No.30 Seksi } 341 \text { (SPAP, 2011). }\end{array}$ & $\begin{array}{l}1=\text { untuk opini audit } \\
\text { going concern. } \\
0=\text { untuk opini audit non } \\
\text { going concern }\end{array}$ & Nominal \\
\hline $\begin{array}{l}\text { Variabel } \\
\text { Independen }(\mathrm{X}) \\
\text { Likuiditas } \\
\text { (X1) } \\
\end{array}$ & $\begin{array}{l}\text { Rasio lancar merupakan rasio untuk mengukur } \\
\text { kemampuan perusahaan dalam membayar kewajiban } \\
\text { jangka pendek atau utang yang segera jatuh tempo } \\
\text { padasaat ditagih secara keseluruhan" Kasmir, 2018:134). }\end{array}$ & $\begin{array}{l}\text { Current ratio = (Aktiva } \\
\text { lancar : utang lancar })\end{array}$ & Rasio \\
\hline $\begin{array}{l}\text { Variabel } \\
\text { Independen } \\
(\mathrm{X}) \text { Profitabilitas (X2) }\end{array}$ & $\begin{array}{l}\text { Untuk mengukur kemampuan Perusahaan dengan } \\
\text { keseluruhan dana yang ditanamkan dalam aktiva yang } \\
\text { digunakan untuk operasi perusahaan yang menghasilkan } \\
\text { keuntungan (Azhar, Hardi dan Satriawan, 2014) }\end{array}$ & 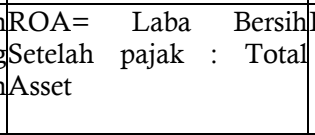 & Rasio \\
\hline $\begin{array}{l}\text { Pertumbuhan } \\
\text { Perusahaan (X3) }\end{array}$ & $\begin{array}{l}\text { Pertumbuhan perusahaan adalah kemampuan perusahaan } \\
\text { untuk meningkatkan aset. Pertumbuhan perusahaan } \\
\text { menunjukkan kemampuan perusahaan } \\
\text { mempertahankan kelangsungan usahanya (Djoko dan } \\
\text { Yanti, 2019) }\end{array}$ & $\begin{array}{l}\text { (Penjualan Tahun ini } \\
\text { Penjualan Tahun lalu) }\end{array}$ & Rasio \\
\hline
\end{tabular}


Metode pengumpulan data dalam penelitian ini adalah dengan menggunakan metode dokumentasi data sekunder berdasarkan laporan keuangan perusahaan farmasi yang terdaftar di Bursa Efek Indonesia tahun 2017-2019. Populasi perusahaan Farmasi yang terdaftar di Bursa Efek Indonesia tahun 2017-2019 sebanyak 10 perusahaan dan sampel yang diperoleh secara purposive sampling sebanyak 8 Perusahaan, karena 2 perusahaan laporan keuangan maupun laporan tahunannya pada periode 2018 tidak ada di Bursa Efek Indonesia.

Tabel 1. Kriteria Sample

\begin{tabular}{|l|c|}
\hline Perusahaan Farmasi yang terdaftar di BEI 2017-2019 & 10 \\
\hline $\begin{array}{l}\text { Perusahaan yang laporan keuangannya tidak lengkap (tidak ada Laporan } \\
\text { keuangan maupun Laporan Tahunannya periode 2018) }\end{array}$ & $(2)$ \\
\hline Total Sample Perusahaan yang diteliti & $\mathbf{8}$ \\
\hline
\end{tabular}

Tabel 2. Sampel

\begin{tabular}{|l|l|l|}
\hline No. & $\begin{array}{c}\text { Kode } \\
\text { Saham }\end{array}$ & \multicolumn{1}{|c|}{ Nama Perusahaan } \\
\hline 1 & DVLA & PT. Daya Varia Laboratoria Tbk. \\
\hline 2 & KAEF & PT. Kimia Farma Tbk. \\
\hline 3 & INAF & PT. Indofarma Tbk. \\
\hline 4 & KLBF & PT. Kalbe Farma Tbk. \\
\hline 5 & SIDO & PT. Industri Jamu dan Farmasi Sido Muncul Tbk. \\
\hline 6 & TSPC & PT. Tempo Scan Pacific Tbk. \\
\hline 7 & PYFA & PT. Pyridam Farma Tbk. \\
\hline 8 & SILO & PT Siloam International Hospitals Tbk. \\
\hline
\end{tabular}

Dalam penelitian ini data yang diperoleh peneliti adalah hasil dari dokumentasi atau bisa disebut juga data sekunder. Menurut Sugiyono (2012:141) mendefinisikan bahwa data sekunder merupakan sumber data yang diperoleh dengan melalui membaca, mempelajari dan memahami dengan menggunakan media lain yang bersumber dari literatur, buku-buku, dan dokumen yang memiliki hubungan erat dengan objek penelitian, antara lain annual report (laporan Tahunan) pada 2017-2019 yang dipublikasikan di situs resmi Bursa Efek Indonesia (BEI).

Sesuai dengan hipotesis yang telah dirumuskan maka analisis yang digunakan adalah analisis statistik deskriptif dengan regresi logistik ( logistic regression), yang pada tahap sebelumnya telah dilakukan uji kualitas data.

\section{HASIL DAN PEMBAHASAN \\ Deskripsi Data Penelitian}

Data penelitian yang digunakan, yaitu perusahaan Jasa yang terdaftar di Bursa Efek Indonesia (BEI). Merujuk pada kriteria pengambilan sample yang telah dilakukan peneliti, maka diperoleh 8 perusahaan dengan 24 sample dalam tahun pengamatan. Berdasarkan data yang telah diolah menggunakan aplikasi SPSS, meliputi variabel dependen yaitu opini audit going concern serta variabel independen, Likuiditas, Profitabilitas, dan Pertumbuhan Perusahaan.

Analisis Statistik Desktiptif menurut Ghozali (2018:19) digunakan untuk memberikan suatu gambaran atau deskripsi variabel-variabel dalam penelitian yang memproses transformasi data ke bentuk tabulasi yang membuat data terlihat dari perolehan nilai ratarata, sstandar deviasi, varian, maksimum, minimum, sum, range, kurtosis dan wekness sehingga mudah dipahami dan diinterpretasikan dengan menggunakan program SPSS Statistic 26 For Windows. Maka untuk hasil atas deskripsi data mengenai variabel-variabel pada penelitian ini dapat dilihat dengan rinci melalui Tabel 4.

Berdasarkan tabel 4. dapat dijelaskan sebagai berikut:

1. Pada variabel Going Concern, baik perusahaan yang mendapatkan opini audit going concern maupun perusahaan yang tidak mendapatkan opini audit going concern
Financial Ratios and Going Concern Audit Opinion 
Financial Ratios and Going Concern Audit Opinion memiliki nilai minimum sebesar 0 dan nilai maksimum sebesar 1 . Kemudian, nilai mean sebesar 0,92 dan nilai standar deviasi sebesar 0,28 dimiliki perusahaan baik perusahaan yang medapatkan opini audit going concern maupun perusahaan yang tidak mendapatkan opini audit going concern.

2. Pada variabel Likuiditas, baik perusahaan yang mendapatkan opini audit going concern maupun perusahaan yang tidak mendapatkan opini audit going concern memiliki nilai minimum sebesar 0,99 dan nilai maksimum sebesar 7,81, sedangkan untuk nilai mean sebesar 2,89 dan nilai standar deviasi sebesar 1,55 dimiliki perusahaan baik perusahaan yang mendapatkan opini audit going concern maupun perusahaan yang tidak mendapatkan opini audit going concern.

3. Pada variabel Profitabilitas, baik perusahaan yang mendapatkan opini audit going concern maupun perusahaan yang tidak mendapatkan opini audit going concern memiliki nilai minimum sebesar $-0,04$ dan nilai maksimum sebesar 0,23 , selain itu nilai mean sebesar 0,07 serta nilai standar deviasi sebesar 0,07 dimiliki perusahaan baik perusahaan yang mendapatkan opini audit going concern maupun perusahaan yang tidak mendapatkan opini audit going concern.

4. Pada variabel Pertumbuhan Perusahaan, baik perusahaan yang mendapatkan opini audit going concern maupun perusahaan yang tidak mendapatkan opini audit going concern memiliki nilai minimum sebesar - 0,14 dan nilai maksimum sebesar 0,38, sedangkan untuk nilai mean sebesar 0,07 dan nilai standar deviasi sebesar 0,09 dimiliki perusahaan baik perusahaan yang mendapatkan opini audit going concern maupun perusahaan yang tidak mendapatkan opini audit going concern.

Tabel 4. Hasil Analisis Statistik Deskriptif

\begin{tabular}{lrrrrr} 
& $\mathrm{N}$ & \multicolumn{2}{c}{ Minimum } & Maximum & \multicolumn{2}{c}{ Mean } & \multicolumn{2}{c}{ Std Deviation } \\
\cline { 2 - 7 } $\begin{array}{l}\text { Opini Audit Going } \\
\text { Concern }\end{array}$ & 24 & .00 & 1.00 & .92 & .28 \\
\hline Likuiditas & & & & & .07 \\
\hline Profitabilitas & 24 & .99 & 7.81 & 2.89 & 1.55 \\
\hline Pertumbuhan Perusahaan & 24 &. .04 & .23 & .07 & .07 \\
Valid N (listwise) & 24 & -.15 & .38 & .07 & .09 \\
\hline Sumbre & 24 & & & & \\
\hline
\end{tabular}

Sumber: Hasil Pengolahan Data dengan IBM SPSS Statistik 26, 2021

\section{Hasil Analisis Regresi Logistik}

Pengujian kelayakan pada model regresi logistik dinilai dengan menggunakan hosmer and lemeshow's goodness of fit test yang diukur dengan nilai chi-(Utami, 2020). Model ini digunakan untuk menguji hipotesis nol bahwa data tersebut cocok atau sesuai dengan model (tidak adanya perbedaan antara model dengan data sehingga model dapat dikatakan fit) (Utami, 2020), maka model untuk uji kelayakan model regresi, seperti berikut:

1. Jika nilai statistik hosmer and lemeshow's goodness of fit test sama dengan atau kurang dari $0,05(0,05)$, maka hipotesis nol (H0) ditolak yang menunjukkan adanya perbedaan signifikan antara model dengan nilai observasinya sehingga dapat dikatakan goodness of fit test artinya tidak baik karena model tersebut tidak dapat memprediksi nilai observasinya.

Tabel 5. Hosmer and Lemeshow Test

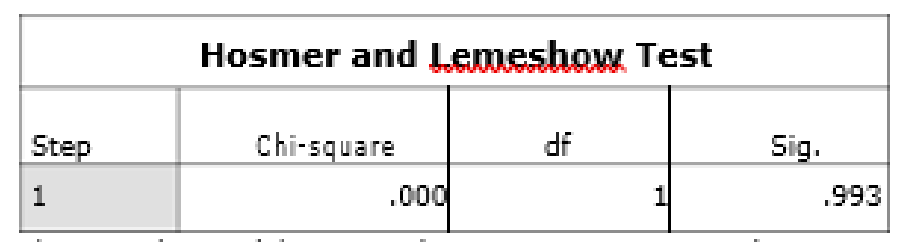

Sumbec: Hasil Rengolaban Data dengan IBM SPSS Statistik. 26, 2021

2. Jika nilai statistik hosmer and lemeshow's goodness of fit test lebih besar dari 0,05 $(0,05)$, maka hipotesis nol (H0) maka hipotesis nol diterima yang menunjukkan model mampu memprediksi nilai observasinya. 
Berdasarkan tabel diatas dapat dilihat bahwa pada nilai Chi-square hasil dari penelitian sebesar 0,000 dengan nilai sig sebesar 0,993 dan df. Nilai signifikansi yang lebih besar dari 0,05 menunjukkan bahwa $\mathrm{H} 0$ dapat diterima dan tidak ada perbedaan antara klasifikasi yang telah diamati dan diprediksi maka dengan ini model regresi logistik dapat digunakan untuk melakukan analisis berikutnya.

Pengujian koefisien determinasi digunakan untuk mengetahui seberapa besar kombinasi pada variabel independen mampu menjelaskan variabilitas variable dependen sedangkan sisanya dijelaskan oleh variabel-variabel luar pada model penelitian dengan"menggunakan model Nagelkerke's $R$ Square (Utami, 2020). Nilai Nagelkerke's $R$ Square bervariasi antara 1 (satu) dan 0 (nol). Dapat dikatakan bahwa apabila nilai tersebut mendekati 1 maka model dianggap semakin goodness of fit sementara nilai tersebut mendekati 0 maka model tidak goodness of fit. Koefisien determinasi (R2) menunjukkan seberapa jauh kemampuan variasi variabel independen dalam menjelaskan variasi variabel dependen (Utami, 2020).

Tabel 6. Model Summary

\begin{tabular}{|l|r|r|c|}
\hline \multicolumn{4}{|c|}{ Model Summary } \\
\hline Step & -2 Log likelihood & $\begin{array}{c}\text { Cox \& Snell R } \\
\text { Square }\end{array}$ & $\begin{array}{c}\text { Nagelkerke R } \\
\text { Square }\end{array}$ \\
\hline 1 & \multicolumn{4}{|c|}{$.000^{\mathrm{a}}$} & .437 & 1.000 \\
\hline \multicolumn{4}{|c|}{$\begin{array}{l}\text { a. Estimation terminated at iteration number } 20 \text { because maximum } \\
\text { iterations has been reached. Final solution cannot be found. }\end{array}$}
\end{tabular}

Berdasarkan hasil yang ditujukan dalam Tabel 6, nilai Nagerkerke R Square yang didapat sebesar 1.000. Artinya, variabel independen secara simultan berpengaruh terhadap variabel dependen sebesar $100 \%$.

Penilaian model fit digunakan untuk menilai model yang telah dihipotesiskan telah fit atau tidak dengan data (Utami, 2020). Hipotesis untuk menilai model fit adalah:

$\mathrm{HO}=$ model yang dihipotesiskan fit dengan data

$\mathrm{HA}=$ model"yang dihipotesiskan tidak fit dengan data

Berdasarkan hipotesis ini, maka"H0 harus diterima dan HA harus ditolak agar model fit dengan data. Statistik yang digunakan berdasarkan pada fungsi Likelihood. Output SPSS memberikan dua nilai -2LogL, "yaitu satu model yang hanya memasukkan"konstanta dan model yang"kedua untuk model dengan konstanta dan variabel bebas (independen). Pengujian ini dilakukan"dengan membandingkan nilai antara:

1. -2Log Likelihood (-2LL) pada awal (block number $=0$ ) dengan nilai -2Log Likelihood pada akhir (block number $=1$ ).

2. Adanya penurunan nilai antara -2LL awal (initial -2LL function) dengan nilai -2LL pada langkah berikutnya (-2LL akhir), menunjukkan bahwa model yang dihipotesiskan fit dengan data.

Pada Tabel 8 perbandingan nilai -2Log Likelihood Awal sebelum dimasukkan variabel bebas (Block Number $=0$ ) diperoleh nilai sebesar 13,768 Sedangkan, pada tabel 4.8 perbandingan nilai -2Log Likelihood Akhir setelah dimasukkan variabel bebas (Block Number =1) diperoleh nilai sebesar 0,000 .

Berdasarkan hasil tersebut, dapat dilihat pada tabel 9 terdapat perbandingan nilai antara -2Log Likelihood Awal dan Akhir sebesar 13,768, perbandingan tersebut berdasarkan sebaran Chi-Square dengan df 3. Perbandingan yang terjadi dapat diartikan bahwa adanya penambahan variabel bebas ke dalam model regresi dapat memperbaiki model fit dan menunjukkan bahwa model regresi yang lebih baik.
Financial Ratios and Going Concern Audit Opinion 
Financial Ratios and Going Concern Audit Opinion

\section{6}

Tabel 7. Hasil Uji Fit I

\begin{tabular}{|c|c|c|c|}
\hline \multicolumn{4}{|c|}{ Iteration History ${ }^{a, b, c}$} \\
\hline \multirow{2}{*}{\multicolumn{2}{|c|}{ Iteration }} & \multirow{2}{*}{$\begin{array}{l}-2 \log \\
\text { likelihood }\end{array}$} & Coefficients \\
\hline & & & Constant \\
\hline \multirow[t]{5}{*}{ Step 0} & 1 & 14.971 & $1.66 \mathrm{~J}$ \\
\hline & 2 & 13.821 & 2.232 \\
\hline & 3 & 13.768 & 2.387 \\
\hline & 4 & 13.768 & 2.398 \\
\hline & 5 & 13.768 & 2.398 \\
\hline \multicolumn{4}{|c|}{ a. Constant is included in the model. } \\
\hline \multicolumn{4}{|c|}{ b. Initial -2 Loq Likelihood: 13.768} \\
\hline \multicolumn{4}{|c|}{$\begin{array}{l}\text { c. Estimation terminated at iteration number } 5 \text { because } \\
\text { parameter estimates changed by less than } .001 \text {. }\end{array}$} \\
\hline
\end{tabular}

Surobec: Output SPSS 26 diolah peneliti (2021)

Tabel 8.Hasil Uji Fit II

\begin{tabular}{|c|c|c|c|c|c|c|}
\hline \multicolumn{7}{|c|}{ Iteration History ${ }^{\mathrm{a}, \mathrm{b}, \mathrm{c}, \mathrm{d}}$} \\
\hline \multirow{2}{*}{\multicolumn{2}{|c|}{ Iteration }} & \multirow[b]{2}{*}{$\begin{array}{l}-2 \text { Log } \\
\text { likelihood }\end{array}$} & \multicolumn{4}{|c|}{ Coefficients } \\
\hline & & & Constant & Likuiditas & Profitabilitas & $\begin{array}{l}\text { Pertumbuhan } \\
\text { Perusahaan }\end{array}$ \\
\hline \multirow{20}{*}{ Step 1} & 1 & 12.987 & 1.404 & .043 & 4.752 & -3.132 \\
\hline & 2 & 9.932 & 1.390 & .254 & 9.035 & -4.632 \\
\hline & 3 & 8.309 & .403 & .862 & 10.786 & -4.545 \\
\hline & 4 & 7.379 & -.691 & 1.661 & 12.020 & -4.755 \\
\hline & 5 & 6.880 & -1.677 & 2.533 & 14.907 & -5.533 \\
\hline & 6 & 6.592 & -2.809 & 3.637 & 19.263 & -6.863 \\
\hline & 7 & 6.398 & -4.389 & 5.243 & 25.505 & -8.971 \\
\hline & 8 & 6.202 & -7.419 & 8.362 & 37.155 & -13.063 \\
\hline & 9 & 5.420 & -24.329 & 25.771 & 100.663 & -35.588 \\
\hline & 10 & 3.098 & -113.563 & 117.821 & 436.376 & -155.119 \\
\hline & 11 & 1.403 & -237.748 & 247.526 & 913.121 & -329.229 \\
\hline & 12 & .449 & -408.026 & 425.223 & 1566.586 & -567.257 \\
\hline & 13 & .158 & -559.252 & 582.971 & 2146.983 & -778.311 \\
\hline & 14 & .057 & -704.903 & 734.889 & 2705.995 & -981.506 \\
\hline & 15 & .021 & -848.674 & 884.842 & 3257.800 & -1182.055 \\
\hline & 16 & .008 & -991.775 & 1034.094 & 3807.031 & -1381.659 \\
\hline & 17 & .003 & -1134.631 & 1183.091 & 4355.327 & -1580.920 \\
\hline & 18 & .001 & -1277.398 & 1331.994 & 4903.279 & -1780.055 \\
\hline & 19 & .000 & -1420.132 & 1480.863 & 5451.105 & -1979.144 \\
\hline & 20 & .000 & -1562.854 & 1629.719 & 5998.885 & -2178.215 \\
\hline
\end{tabular}

a. Method: Enter

b. Constant is included in the model.

c. Initial -2 Log Likelihood: 13.768

d. Estimation terminated at iteration number 20 because maximum iterations has been reached. Final solution cannot be found.

Sumber: Hasil Pengolahan Data dengan IBM SPSS Statistik 26, 2021

Matriks klasifikasi merupakan cara untuk mengetahui kekuatan prediksi dari model regresi logistik guna memprediksi kemungkinan terjadinya pergantian KAP yang dilakukan oleh perusahaan (Bulkis, 2018).

Berdasarkan tabel diatas, menunjukkan bahwa kekuatan prediksi dari model regresi dalam memprediksi kemungkinan perusahaan menerima opini audit going concern sebesar $100 \%$. yang berarti bahwa, dengan menggunakan model regresi tersebut terdapat sebanyak 22 pengamatan dari 24 pengamatan yang diprediksi menerima opini audit going concern. Kemudian pada kekuatan prediksi dari model regresi dalam memprediksi kemungkinan perusahaan menerima opini audit non going concern sebesar $100 \%$ yang berarti bahwa, dengan menggunakan model regresi tersebut terdapat sebanyak 2 perusahaan dari 24 perusahaan yang diprediksi menerima opini audit non going concern. Dan dilihat dari secara keseluruhan kekuatan prediksi dari model regresi dalam penelitian ini adalah sebesar $100 \%$ yang berarti bahwa, kemampuan prediksi dari model regresi 
dengan variabel Likuiditas, Profitabilitas, dan Pertumbuhan Perusahaan secara statistik dapat memprediksi sebesar $100 \%$.

Tabel 9. Classfication Table

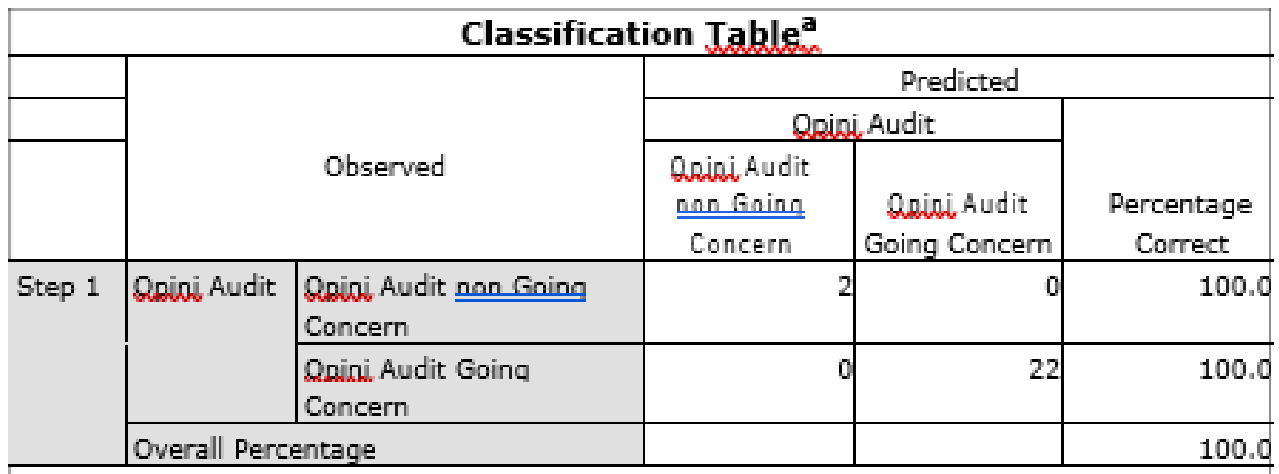

a. The cut value is .500

Sumber:Hasil Pengolahan Data dengan IBM SPSS Statistik 26, 2021

\section{Hasil Pengujian Hipotesis}

a) Uji parsial

dilakukan dengan memasukkan seluruh variabel independen dan variabel dependen. Dalam uji parsial, apabila nilai signifikan menunjukkan $<0,05$ maka dapat dikatakan berpengaruh, dan sebaliknya apabila nilai signifikan menunjukkan $>0,05$ maka dapat dikatakan tidak berpengaruh (Utami, 2020).

\section{Tabel 10. Hasil Uji Parsial}

\begin{tabular}{|c|c|c|c|c|c|c|c|c|c|}
\hline \multicolumn{10}{|c|}{ Variables in the Equation } \\
\hline & & \multirow[b]{2}{*}{ B } & \multirow[b]{2}{*}{ S.E. } & \multirow[b]{2}{*}{ Wald } & \multirow[b]{2}{*}{$d f$} & \multirow[b]{2}{*}{ Sig. } & \multirow[b]{2}{*}{$\operatorname{Exp}(B)$} & \multicolumn{2}{|c|}{$\begin{array}{c}95 \% \text { Calfor } \\
\operatorname{EXP}(B)\end{array}$} \\
\hline & & & & & & & & Lower & Upper \\
\hline \multirow{4}{*}{$\begin{array}{l}\text { Step } \\
1^{a}\end{array}$} & Likuiditas. & 1629.719 & 17954.054 & .008 & 1 & .928 & & .000 & \\
\hline & Profitabilitas & 5998.885 & 66004.309 & .008 & 1 & .928 & & .000 & \\
\hline & $\begin{array}{l}\text { Rertumbubaro. } \\
\text { Perusahaan }\end{array}$ & 2178.215 & 23927.150 & .008 & 1 & .927 & .000 & .000 & \\
\hline & Constant & 1562.854 & 17243.946 & .008 & 1 & .928 & .000 & & \\
\hline
\end{tabular}

Sucobec: Hasil Rengolaban Data depqan IBM SPSS Statistik 26, 2021

Berdasarkan pada tabel diatas maka untuk regresi logistik yang terbentuk seperti berikut: $\mathrm{Y}=-1562.854+1629.719 \mathrm{X} 1+5998.885 \mathrm{X} 2+-2178.215 \mathrm{X} 3$

a. Variabel Konstanta model regresi logistik memiliki koefisien negatif sebesar 1562,854 yang dapat diartikan apabila variabel lainnya dianggap nol maka Opini Audit Going Concern mengalami penurunan sebesar 1562.854 .

b. Variabel Likuiditas (X1) menunjukkan bahwa diperoleh koefisien regresi Positif sebesar 1629.719 dengan tingkat signifikansi diperoleh sebesar 0,928 yang berarti lebih tinggi dari 0,05. Maka hal ini menunjukkan bahwa pada variabel Likuiditas tidak berpengaruh secara signifikan terhadap Opini Audit Going Concern.

c. Variabel Profitabilitas (X2) menunjukkan bahwa diperoleh koefisien regresi positif sebesar 5998.885 dengan tingkat signifikansi diperoleh sebesar 0,928 yang berarti lebih tinggi dari 0,05. Maka hal ini menunjukkan bahwa pada variabel Profitabilitas tidak berpengaruh secara signifikan terhadap Opini Audit Going Concern

d. Variabel Pertumbuhan Perusahaan (X3) menunjukkan bahwa diperoleh koefisien regresi negatif sebesar -2178.215 dengan tingkat signifikansi diperoleh sebesar 0,927 yang berarti lebih tinggi dari 0,05 . Maka hal ini menunjukkan bahwa pada variabel ukuran perusahaan tidak berpengaruh secara signifikan terhadap Opini Audit Going Concern.

Financial Ratios and Going Concern Audit Opinion 
Financial Ratios and Going Concern Audit Opinion

\section{b) Uji Statistik F (Secara Simultan)}

Uji F menurut Ghozali (2016:96) yaitu suatu uji yang dilakukan guna melihat seberapa besar pengaruh variabel independen secara simultan dapat berpengaruh terhadap variabel dependen. Uji F dapat dilihat dari pengaruh antara variabel X1, X2, X3, dan X4 secara simultan terhadap variabel dependen $\mathrm{Y}$, dengan level of significance yang digunakan $5 \%$ atau $(\alpha)=0,05$, maka berikut kriteria pengujian yang dilakukan:

1. Jika fhitung < ftabel atau signifikansi $>0,05$. Maka Ho diterima yang menjelaskan bahwa tidak terdapat pengaruh secara simultan antara variabel independen dengan variabel dependen secara signifikan.

2. Jika fhitung $>\mathrm{ftabel}$ atau signifikansi $<0,05$. Maka Ho ditolak yang mengindikasikan bahwa terdapat pengaruh secara simultan antara variabel independen dengan variabel dependen secara signifikan.

Tabel 11. Hasil Uji F Simultan

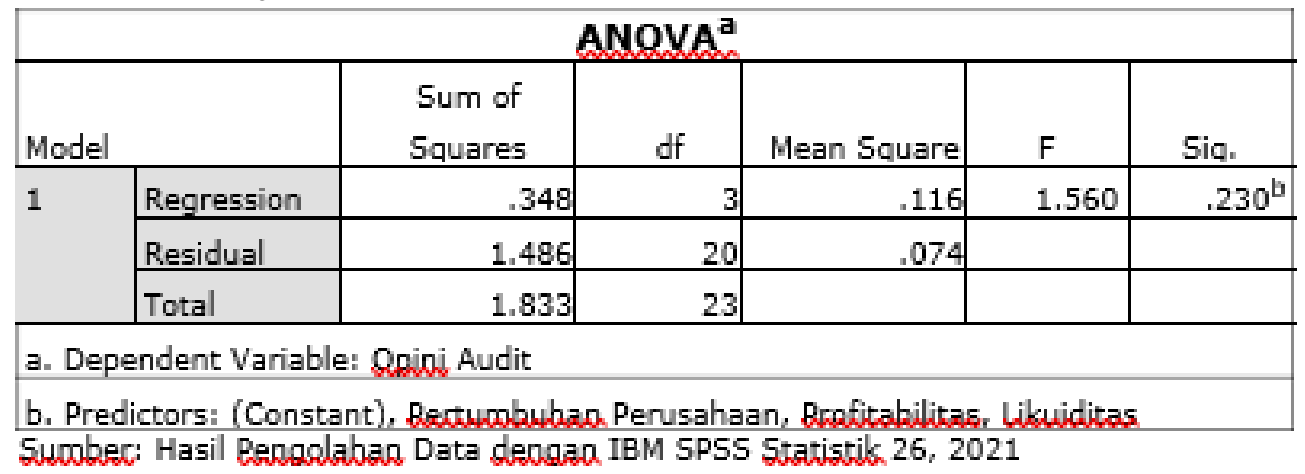

Berdasarkan tabel tersebut menghasilkan nilai Fhitung sebesar 1,560 dengan nilai sig sebesar 0,230. Maka, nilai Ftabel dapat dihitung dengan df $1=\mathrm{k}-1=4-1=3$, dan df $2=\mathrm{n}-\mathrm{df} 1=24-3=21$ ( $\mathrm{n}$ adalah jumlah pengamatan yang digunakan dan $\mathrm{k}$ adalah jumlah variabel yang digunakan), sehingga didapat nilai Ftabel sebesar 3,07. Berdasarkan hasil tersebut, maka dapat disimpulkan bahwa Fhitung $<$ Ftabel dan nilai sig $>0,05$, hal ini menandakan bahwa H0 diterima. Artinya, pada variabel Likuiditas, Profitabilitas, dan Pertumbuhan Perusahaan secara simultan tidak memiliki pengaruh terhadap opini audit going concern.

\section{Pembahasan Hasil Penelitian}

Penelitian ini dilakukan untuk mengetahui apakah terdapat pengaruh antara variabel independen yaitu Likuiditas, Profitabilitas, dan Pertumbuhan Perusahaan terhadap variabel dependen yaitu Opini Audit Going Concern pada perusahaan sektor Farmasi yang telah terdaftar di Bursa Efek Indonesia pada tahun 2017-2019.

1. Pengaruh Likuiditas terhadap Opini Audit Going Concern pada Perusahaan Sektor Farmasi yang ter listing di BEI tahun 2017-2019.

Hipotesis pertama untuk pengujian yang dilakukan pada regresi logistik memperlihatkan bahwa Likuiditas memperoleh koefisien regresi positif sebesar 1629,719 yang menyatakan bahwa setiap kenaikan opini audit sebesar 1 satuan akan menaikan Opini Audit Going Concern pada perusahaan sektor Farmasi yang terdaftar di bursa efek indonesia pada tahun 2017-2019 sebesar 1629,719 satuan. Dengan diperoleh tingkat signifikansi sebesar 0,928 yang lebih tinggi dari 0,05, maka hipotesis ke-1 tidak berhasil didukung.

Penelitian ini membuktikan bahwa Likuiditas tidak berpengaruh terhadap Opini Audit Going Concern sebab dari seluruh perusahaan yang mendapat Opini Audit Going Concern 22 dari 24 total pengamatan, dan yang mendapatkan Opini Audit Non Going Concern didapatkan 2 dari 24 total pengamatan menyimpulkan bahwa Likuiditas tidak berpengaruh terhdap adanya Opini Audit Going Concern. Hal ini sejalan dengan pendapat Herry Sussanto, Nur Mettani Aquariza,(2013) yang mengatakan bahwa Likuiditas tidak berpengaruh terhadap Opini Audit Going Concern. Namun untuk hasil pada penelitian ini tidak sesuai dengan hasil penelitian yang dilakukan Aria Masdiana 
Pasaribu (2015) yang mengatakan bahwa opini audit berpengaruh terhadap Opini Audit Going Concern. Semakin tinggi persentase likuiditas perusahaan maka semakin tinggi juga perusahaan mendapatkan opini audit Going Concern dari seorang auditor.

2. Pengaruh Profitabilitas terhadap Opini Audit Going Concern pada Perusahaan Sektor Farmasi yang terdaftar di BEI tahun 2017-2019.

Hipotesis kedua untuk pengujian yang dilakukan pada regresi logistik memperlihatkan bahwa Profitabilitas memperoleh koefisien regresi positif sebesar 5998,885 yang menyatakan bahwa setiap kenaikan Profitabilitas sebesar 1 satuan akan menaikkan Opini Audit Going Concern pada perusahaan sektor Farmasi yang terdaftar di bursa efek indonesia pada tahun 2017-2019 sebesar 5998,885 satuan. Dengan diperoleh tingkat signifikansi sebesar 0,928 yang lebih tinggi dari 0,05 , maka hipotesis ke-2 tidak berhasil didukung.

Hasil pada penelitian ini mendukung untuk penelitian yang dilakukan oleh Ferni Listantri, Rina (2016), Al Azhar A, Hardi \& Ricky Rusydi Satriawan,(2014) yang melakukan penelitian terhadap Opini Audit Going Concern pada perusahaan yang terdafta di bursa efek indonesia dimana mereka memberikan pendapat bahwa Profitabilitas tidak Berpengaruh Terhadap Opini Audit Going Concern. Hasil pengujian menunjukan bahwa semakin tinggi persentase profitabilitas perusahaan maka semakin kecil pula keputusan auditor untuk memberikan opini audit Non Going Concern. Namun untuk hasil penelitian ini tidak sejalan dengan hasil penelitian yang telah dilakukan oleh Meria Yani, Rina Asmeri, Nurul Andini(2018), yang mengatakan bahwa Profitabilitas berpengaruh secara signifikan terhadap Opini Audit Going Concern.

3. Pengaruh Pertumbuhan Perusahaan terhadap Opini Audit Going Concern pada Perusahaan Sektor Farmasi yang terdaftar di BEI tahun 2017-2019.

Hipotesis ketiga untuk pengujian yang dilakukan pada regresi logistik memperlihatkan bahwa ukuran perusahaan memperoleh koefisien regresi negatif sebesar $-2178,215$ yang menyatakan bahwa setiap kenaikan ukuran perusahaan sebesar 1 satuan akan menurunkan Opini Audit Going Concern pada perusahaan sektor Farmasi yang terdaftar di bursa efek indonesia pada tahun 2017-2019 sebesar 2178,215 satuan. Dengan diperoleh tingkat signifikansi sebesar 0,927 yang lebih tinggi dari 0,05, maka hipotesis ke-3 tidak berhasil didukung.

Hasil penelitian ini Berbanding lurus dengan penelitian yang dilakukan oleh Syafriliani (2015) dan Yudia Rosiana Putri, Hardiwinoto, Alwiyah (2019) yang mengatakan bahwa Pertumbuhan tidak memberikan pengaruh terhadap Opini Audit Going Concern. Karena menurun pertumbuhan perusahaan belum tentu menjadikan perusahaan tersebut akan mengalami kebangkrutan dimasa mendatang atau non going concern, karena peran manajemen perusahaan pun sangat penting karena setiap rencana strategis dari seorang manager perusahaan akan menentukan bagaimana memperbaiki pertumbuhan perusahaan tersebut. Namun untuk hasil pada penelitian ini bertentangan dengan hasil penelitian yang telah dilakukan oleh Ira Kristiana (2012) dan Diah Rahmawati , Endang Dwi Wahyuningsih , Ira Setiawati (2018) yang mengatakan bahwa Pertumbuhan Perusahaan berpengaruh secara signifikan terhadap Opini Audit Going Concern.

4. Pengaruh Likuiditas, Profitabilitas, dan Pertumbuhan Perusahaan terhadap Opini Audit Going Concern pada Perusahaan Sektor Farmasi yang ter daftar di BEI tahun 2017-2019.

Berdasarkan pada hasil pengujian yang telah dilakukan oleh peneliti ditemukan bahwa Likuiditas, Profitabilitas, dan Pertumbuhan Perusahaan secara simultan tidak memiliki pengaruh terhadap Opini Audit Going Concern. Hal ini dapat bahwa nilai fhitung sebesar 1,560 dengan nilai Sig sebesar 0,230. Sedangkan untuk nilai ftabel diperoleh sebesar 3,07. Maka berdasarkan hasil tersebut, dapat diambil suatu kesimpulan bahwa fhitung $<$ ftabel dan nilai sig $>0,05$. Sehingga dapat dipastikan bahwa Likuiditas, Profitablitas, dan Pertumbuhan Perusahaan tidak berpengaruh
Financial Ratios and Going Concern Audit Opinion

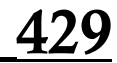


Financial Ratios and Going Concern Audit Opinion

430 secara simultan terhadap Opini Audit Going Concern pada perusahaan sektor Farmasi yang terdaftar di Bursa Efek Indonesia pada tahun 2017-2019. Maka untuk nilai yang diperoleh Nagelkerke $R$ Square sebesar 1,000 (100\%) dapat diartikan bahwa untuk variabel independen yaitu Likuiditas, Profitabilitas, Pertumbuhan Perusahaan dapat menerangkan variabel dependen Opini Audit Going Concern sebesar 100\%.

\section{PENUTUP}

Berdasar dari analisis yang dilakukan oleh peneliti yaitu Pengaruh Likuiditas, Profitabilitas,, dan Pertumbuhan Perusahaan terhadap Opini Audit Going Consern pada perusahaan sektor Farmasi yang telah terdaftar di Bursa Efek Indonesia pada tahun 20172019. Analisis dilakukan dengan menggunakan analisis regresi logistik yang telah diolah menggunakan program SPSS versi 26, dengan jumlah total pengamatan sebesar 24 dengan 8 perusahaan yang terdaftar pada BEI di tahun 2017-2019.

Maka berdasarkan penelitian yang telah dilakukan dapat disimpulkan seperti berikut:

1. Likuiditas memiliki nilai signifikansi sebesar 0,928 yang lebih besar dari $0,05(0,928$ $>0,05)$. Hasil uji hipotesis parsial dapat diperoleh kesimpulan bahwa Likuiditas tidak berpengaruh secara parsial terhadap opini audit going concern.

2. Profitabilitas memiliki nilai signifikansi sebesar 0,928 yang lebih besar dari $0,05(0,928$ $>0,05)$. Hasil uji hipotesis parsial dapat diperoleh kesimpulan bahwa Profitabilitas tidak berpengaruh secara parsial terhadap opini audit going concern.

3. Pertumbuhan Perusahaan memiliki nilai signifikansi sebesar 0,927 yang lebih besar dari $0,05(0,927>0,05)$. Hasil uji hipotesis parsial dapat diperoleh kesimpulan bahwa Pertumbuhan Perusahaan tidak berpengaruh secara parsial terhadap opini audit going concern.

4. Likuiditas, Profitabilitas, Pertumbuhan Perusahaan secara simultan tidak memiliki pengaruh terhadap Opini Audit Going Concern pada perusahaan sektor Farmasi yang terdaftar di BEI tahun 2017-2019.

\section{DAFTAR PUSTAKA}

A Al Azhar, Dkk. 2014. "Pengaruh Audit Lag, Profitabilitas, Dan Kualitas Audit Terhadap Pemberian Opini Audit Going Concern Pada Perusahaan Wholesale Dan Retail Trade Listing Di Bei Periode 2010-2012". Neliti.Com

Alichia, Yashinta Putri. 2008. "Pengaruh Ukuran Perusahaan, Pertumbuhan Perusahaan, Dan Opini Audit Tahun Sebelumnya Terhadap Opini Audit Going Concern (Studi Empiris Perusahaan Manufaktur Yang Terdaftar Pada Bursa Efek Indonesia)". Scholar.

Arma, Endra Ulkri. 2013. "Pengaruh Profitabilitas, Likuiditas, Dan Pertumbuhan

Perusahaan Terhadap Penerimaan Opini Audit Going Concern (Studi Empiris Perusahaan Manufaktur Yang Terdaftar Pada Bursa Efek Indonesia)". Ejournal.

Djoko, Lia Dama Yanti. 2019." Pengaruh Pertumbuhan Perusahaan, Profitabilitas, Masa Kerja Audit, Dan Ukuran Kantor Akuntan Publik Terhadap Penerimaan Opini Audit Going Concern". Diambil Pada 20 Oktober 2020 Di Https://Jurnal.Kdi.Or.Id/Index.Php/Ef

Ghozali, Imam. 2011. "Aplikasi Analisis Multivariate Dengan Program Spss". Semarang: Badan Penerbit Universitas Diponegoro.

Ghozali, Imam. 2016. "Aplikasi Analisis Multivariate Dengan Program Spss 23". Semarang: Badan Penerbit Universitas Diponegoro.

Ghozali, Imam. 2018. Aplikasi Analisis Multivariate Dengan Program Ibm Spss 25. Semarang: Badan Penerbit Universitas Diponegoro.

Gultom, Caroline. 2019. "Pengaruh Company Growth, Return On Assets, Leverage Dan Nilai Perusahaan Terhadap Opini Audit Going Concern Pada Perusahaan Publik Di Indonesia". Neliti.Com

Setiadamayanthi, Wirakusuma. 2016. "Pengaruh Auditor Switching Dan 
Financial Distress Pada Opini Audit Going Concern ". Diambil Pada 17 Desember 2020 Di Https://Ojs.Unud.Ac.Id/Index.Php/Akuntansi/Article/View/15874

Sutedja Christian, 2010. "Faktor-Faktor Yang Berpengaruh Terhadap Pemberian Opini $\mathrm{Au}$ ])It Going Concern Pada Perusahaa Manufaktur". Neliti.Com

Kristiana, Ira. 2012. " Pengaruh Ukuran Perusahaan, Profitabilitas, Likuiditas, Pertumbuhanperusahaan Terhadap Opini Audit Going Concern Pada Perusahaan Manufaktur Yang Terdaftar Di Bursa Efek Indonesia (Bei)". Neliti.Com

Lisa, Oyong. 2012. "Asimetri Informasi Dan Manajemen Laba: Suatu Tinjauan Dalam Hubungan Keagenan" Scholar.

Listantri, Ferni , Rina Mudjiyanti. 2016. "Analisis Pengaruh Financial Distress, Ukuran Perusahaan, Solvabilitas, Dan Profitabilitas Terhadap Penerimaan Opini Audit Going Concern". Jurnal Manajemen Dan Bisnis Media Ekonomi Volume Xvi, No.1

Noverio, Rezkhy. 2011. "Analisis Pengaruh Kualitas Auditor, Likuiditas, Profitabilitas Dan Solvabilitas Terhadap Opini Audit Going Concern Pada Perusahaan Manufaktur Yang Terdaftar Di Bursa Efek Indonesia". Neliti.Com

Pasaribu , Aria Masdiana. 2015. " Pengaruh Kualitas Auditor, Likuiditas, Solvabilitas Dan Profitabilitas Terhadap Opini Audit Going Concern Pada Sub Sektor Makanan Dan Minuman Yang Terdaftar Di Bursa Efek Indonesia" Neliti.Com

Putri, Yudia Rosiana, Dkk. 2019. "Pengaruh Ukuran Perusahaan, Debt Default, Disclosure, Opini Audit Tahun Sebelumnya, Dan Pertumbuhan Perusahaan Terhadap Penerimaan Opini Audit Going Concern Pada Perusahaan Manufaktur Industri Dasar Dan Kimia Di Bursa Efek Indonesia Tahun 2013-2017”. Neliti.Com Https://Media.Neliti.Com/Media/Publications/329434-Pengaruh-Ukuran-

Perusahaan-Debt-Default-5d4b46fd.Pdf : Diakses Pada 03 November 2020

Rahmawati, Diah, Dkk. 2018. "Pengaruh Likuiditas, Ukuran perusahaan, Pertumbuhan Perusahaan, Danopini Audit Tahun Sebelumnya Terhadap Opini Audit Going Concern Pada Perusahaan Manufaktur Yang Terdaftar Di Bursa Efek Indonesia".

Sugiyono. (2013). Metode Penelitian Kuantitatif, Kualitatif Dan R\&D. Bandung: Alfabeta.

Sugiyono. (2013). Statistika Untuk Penelitian. Bandung: Alfabeta

Sugiyono. 2014. Metode Penelitian Kuantitatif, Kualitatif Dan R\&D. Bandung: Alfabeta.

Sussanto, Herry, Nur Mettani Aquariza. 2013. "Analisis Pengaruh Opini Audit Tahun Sebelumnya, Kualitas Auditor, Profitabilitas, Likuiditas, Dan Solvabilitas Terhadap Pemberian Opini Audit Going Concern Pada Perusahaan Consumer Goods Industry Yang Terdaftar Di Bursa Efek Indonesia". Neliti.Com

Syafriliani. 2015. "Pengaruh Kualitas Audit, Likuditas, Kondisi Keuangan Perusahaan, Ukuran Perusahaan, Pertumbuhan Perusahaan Dan Opini Audit Tahun Sebelumnya Terhadap Pengungkapan Going Concern Pada Perusahaan Manufaktur Di Bursa Efek Indonesia Tahun 2011-2013".Neliti.Com : Https://Media.Neliti.Com/Media/Publications/33921-Id-Pengaruh-KualitasAudit-Likuditas-Kondisi-Keuangan-Perusahaan-Ukuran-Perusahaan.Pdf Diakses Pada 15 Juni 2021

Utami, Sri. 2020. "Pengaruh Opini Audit Tahun Sebelumnya, Debt Default, Dan Profitabilitas Terhadap Opini Audit Going Concern (Studi Empiris Pada Perusahaan Sektor Infrastruktur, Utilitas, Dan Transportasi Yang Terdaftar Di Bursa Efek Indonesia). Neliti.Com.

Wati, Endang Ambar. 2016. “ Analisis Kinerja Keuangan Menggunakan Rasio Likuiditas Pada Bumdes Makmur Sejahtera Desa Kepenuhan Raya Tahun 20112015 ". Neliti.Com

Yani, Meria Yani, Dkk. 2018. " Analisis Pengaruh Profitabilitas, Cash Flow, Dan Kebijakan Manajemen Terhadap Opini Audit Going Concern Pada Perusahaan
Financial Ratios and Going Concern Audit Opinion 
Financial Ratios and Going Concern Audit Opinion

\section{2}

Manufaktur Yang Terdaftar Di Bursa Efek Indonesia “. Indonesian Indovisi Institute (Iii).

[Internet]. Rizka Gusti Anggraini [Diakses Pada Tanggal 02 November 2020].

Tersedia Pada :

Https://Katadata.Co.Id/Safrezifitra/Berita/5e9a551367330/Menperin-

Industri-Farmasi-Nasional-Tumbuh-446-Tahun-Lalu

[Internet]. Kasmir [Diakses Pada Tanggal 02 November 2020].

Tersedia Pada : Http://Eprints.Polsri.Ac.Id/

[Internet]. Dwi Niken Tari [Diakses Pada Tanggal 16 Desember 2020].

Tersedia Pada : Https://Market.Bisnis.Com/Read/20191118/192/1171572/Bei-

Sigmagold-Tmpi-Mengalami-Masalah-Going-Concern

[Internet]. Arens, Loebbecke [Diakses Pada Tanggal 14 Desember 2020].

Tersedia Pada: Www.Hestanto.Web.Id

[Internet]. Pernyataan Standar Auditing No.30 Seksi 341 [Diakses Pada Tanggal 14 Desember 2020].

Tersedia Pada

Https://Www.Coursehero.Com/File/P422bdj1/23-Pernyataan-Standar-

Auditing-Psa-No-30-Psa-No30-Seksi-341-Tentang/

[Internet]. Psa No.29 Paragrap 11 Huruf C[Diakses Pada Tanggal 14 Desember 2020]. Tersedia Pada : Https://Www.Coursehero.Com/File/P422bdj1/23-PernyataanStandar-Auditing-Psa-No-30-Psa-No30-Seksi-341-Tentang/

[Internet].Sukrisno Agoes [Diakses Pada Tanggal 14 Desember 2020].

Tersedia Pada : Https://Media.Neliti.Com/Media/Publications/277717-Faktor-

Faktor Yang-Mempengaruhi-Audit-Ju-A9630048.Pdf

[Internet]. Asobac ( A Statement Of Basic Auditing Concepts ) [Diakses Pada Tanggal 14 Desember 2020]. Tersedia Pada : Www.Hestanto.Web.Id

[Internet]. Sugiyono[Diakses Pada Tanggal 15 Desember 2020]. Tersedia Pada: Https://Dspace.Uc.Ac.Id/Bitstream/Handle/123456789/1904/Bab\%203. Pdf?Sequence $=4 \&$ Isallowed $=Y$

[Internet]. Puput Tri Komalasari, 1999[Diakses Pada Tanggal 02 November 2020]. Tersedia Https://Scholar.Google.Co.Id/Citations?View_Op=View_Citation\&H1=En\&U Ser=G6jnc2aaaaaj\&Citation_For_View=G6jnc2aaaaaj:Qjmakfhdy7sc

Internet]. Puput Tri Komalasari, 1999[Diakses Pada Tanggal 02 November 2020]. Tersedia Pada: Http://Repository.Uin-

Suska.Ac.Id/13183/8/8.\%20bab\%20iii_2018363adn.Pdf 